\title{
Electrochemical Nitric Oxide Reduction on
}

\section{Metal Surfaces}

\author{
Hao Wan, Alexander Bagger, and Jan Rossmeisl* \\ Center for High Entropy Alloy Catalysis (CHEAC), Department of Chemistry, University \\ of Copenhagen, Universitetsparken 5, DK-2100 Copenhagen, Denmark \\ E-mail: Jan.Rossmeisl@chem.ku.dk
}

\begin{abstract}
Electrocatalytic denitrification is a promising technology for removing $\mathrm{NO}_{x}$ species $\left(\mathrm{NO}_{3}{ }^{-}, \mathrm{NO}_{2}{ }^{-}\right.$and $\left.\mathrm{NO}\right)$. For $\mathrm{NO}_{x}$ electroreduction $\left(\mathrm{NO}_{x} \mathrm{RR}\right)$, there is a desire for understanding the catalytic parameters that control the product distribution. Here, we elucidate selectivity and activity of catalyst for $\mathrm{NO}_{x} \mathrm{RR}$. At low potential we classify metals by the binding of $* \mathrm{NO}$ versus $* \mathrm{H}$. Analogous to classifying $\mathrm{CO}_{2}$ reduction by $* \mathrm{CO}$ vs $* \mathrm{H}, \mathrm{Cu}$ is able to bind $* \mathrm{NO}$ while not binding $* \mathrm{H}$ giving rise to a selective $\mathrm{NH}_{3}$ formation. Besides being selective, $\mathrm{Cu}$ is active for the reaction found by an activity-volcano. For metals that does not bind NO the reaction stops at NO, similar to $\mathrm{CO}_{2}$-to-CO. At potential above $0.3 \mathrm{~V}$ vs $\mathrm{RHE}$, we speculate a low barrier for $\mathrm{N}$ coupling with $\mathrm{NO}$ causing $\mathrm{N}_{2} \mathrm{O}$ formation. The work provide a clear strategy for selectivity and aims to inspire future research on $\mathrm{NO}_{x} \mathrm{RR}$.
\end{abstract}

\section{Keywords}

$\mathrm{NO}_{x}$ Removal, Ammonia Synthesis, Metal Surfaces, DFT, Electrocatalysis 


\section{Introduction}

Nitrogen can be transformed through biological and physical processes within the nitrogen cycle to form a broad spectrum of inorganic compounds, including ammonia $\left(\mathrm{NH}_{3}\right)$, hydrazine $\left(\mathrm{N}_{2} \mathrm{H}_{4}\right)$, hydroxylamine $\left(\mathrm{NH}_{2} \mathrm{OH}\right)$, nitrite $\left(\mathrm{NO}_{2}{ }^{-}\right)$, nitrate $\left(\mathrm{NO}_{3}{ }^{-}\right)$, nitric oxide $(\mathrm{NO})$, and nitrous oxide $\left(\mathrm{N}_{2} \mathrm{O}\right) . \underline{112}$ While many of these processes are essential to life, largescale commercial food production has led to over-fertilization and consequent accumulation of nitrate and nitrite ions in groundwater and in agricultural runoff streams. Both nitrate and nitrite ions are a source of pollution in groundwater, lakes, and coastal water, causing serious health problems, such as methemoglobinemia and cancer, when ingested in high concentrations. ${ }^{3}$ [5 As a result, groundwater treatments to reduce the concentration of these ions have been developed and have become an important environmental consideration. $\underline{66}$

Meanwhile, the artificial $\mathrm{N}_{2}$ fixation towards $\mathrm{NH}_{3}$ is produced via the Haber-Bosch process. In the Haber-Bosch process, $\mathrm{NH}_{3}$ is produced in a reaction between $\mathrm{H}_{2}$ and $\mathrm{N}_{2}$ at high pressure and temperature. As a consequence, the Haber-Bosch process depends on the use of gaseous $\mathrm{H}_{2}$ which is commonly made from fossil fuel steam methane reforming (SMR). By contrast, the electrochemical conversion of $\mathrm{NO}_{x}\left(\mathrm{x}=1,2\right.$, and 3) to $\mathrm{NH}_{3}$ involves only $\mathrm{H}^{+}$and electrons from electricity that can be from sustainable sources, like wind and solar energy.

Electrochemical denitrification is a promising strategy for the removal of $\mathrm{NO}_{x}$ species from waste-water and constitutes a plausible alternative to traditional denitrification methods, such as biological and physical separations processes, due to its environmental compatibility, energy efficiency, safety, product selectivity, and potential for use in smaller-scale devices. 6 -14 Nitrate and nitrite electroreduction can produce a variety of products, such as $\mathrm{N}_{2}, \mathrm{~N}_{2} \mathrm{O}$, $\mathrm{NH}_{3}$, and $\mathrm{NH}_{2} \mathrm{OH} \cdot{ }^{7 / 9|15| 16}$ The reduction of $\mathrm{NO}$ is an essential environmental reaction, since it determines the performance of waste-water treatment catalysts for $\mathrm{NO}_{3}{ }^{-}, \mathrm{NO}_{2}{ }^{-}$and $\mathrm{NO}$ removal. 617

Investigating electrochemical NO reduction is a first step toward understanding the fun- 
damentals of electrocatalytic $\mathrm{NO}_{3}{ }^{-} / \mathrm{NO}_{2}{ }^{-}$reduction and developing improved electrochemical denitrification or even sufficient $\mathrm{NH}_{3}$ production technologies. ${ }^{6 / 79 \mid 17}[19]$ In addition, the study of NO electrochemistry is of fundamental scientific interest because observations and developed methods can be straightforwardly applied to other environmentally friendly electrocatalytic reduction chemistries. Indeed, as we will show, the electrochemistry of NO has numerous analogies to $\mathrm{CO}_{2} / \mathrm{CO}$ electroreduction, which has been reported before. $\frac{20121}{21}$

In this work, we study the potential dependence of the electrocatalytic reduction of NO among a group of metals via density functional theory (DFT) simulations. We classify metals for the electrochemical reduction of $\mathrm{NO}_{3}{ }^{-} / \mathrm{NO}_{2}{ }^{-} / \mathrm{NO}$, to understand what surface properties determine the main product during reduction, which has been found to be: $\mathrm{H}_{2}, \mathrm{NH}_{3}, \mathrm{~N}_{2}$ and $\mathrm{N}_{2} \mathrm{O}$. The analysis has been split into two potential regions according to experimental results as shown in Fig. 1, low and high potential. In each potential region, a descriptorbased method has been utilized to explain experimental observations of the various products formation. Especially under low potential, activity volcano has been constructed against the adsorption energy of $* \mathrm{~N}$, and $\mathrm{Cu}$ has been demonstrated as the most selective and active metal here for NO reduction since it adsorbs $*$ NO but not $* \mathrm{H}$. 

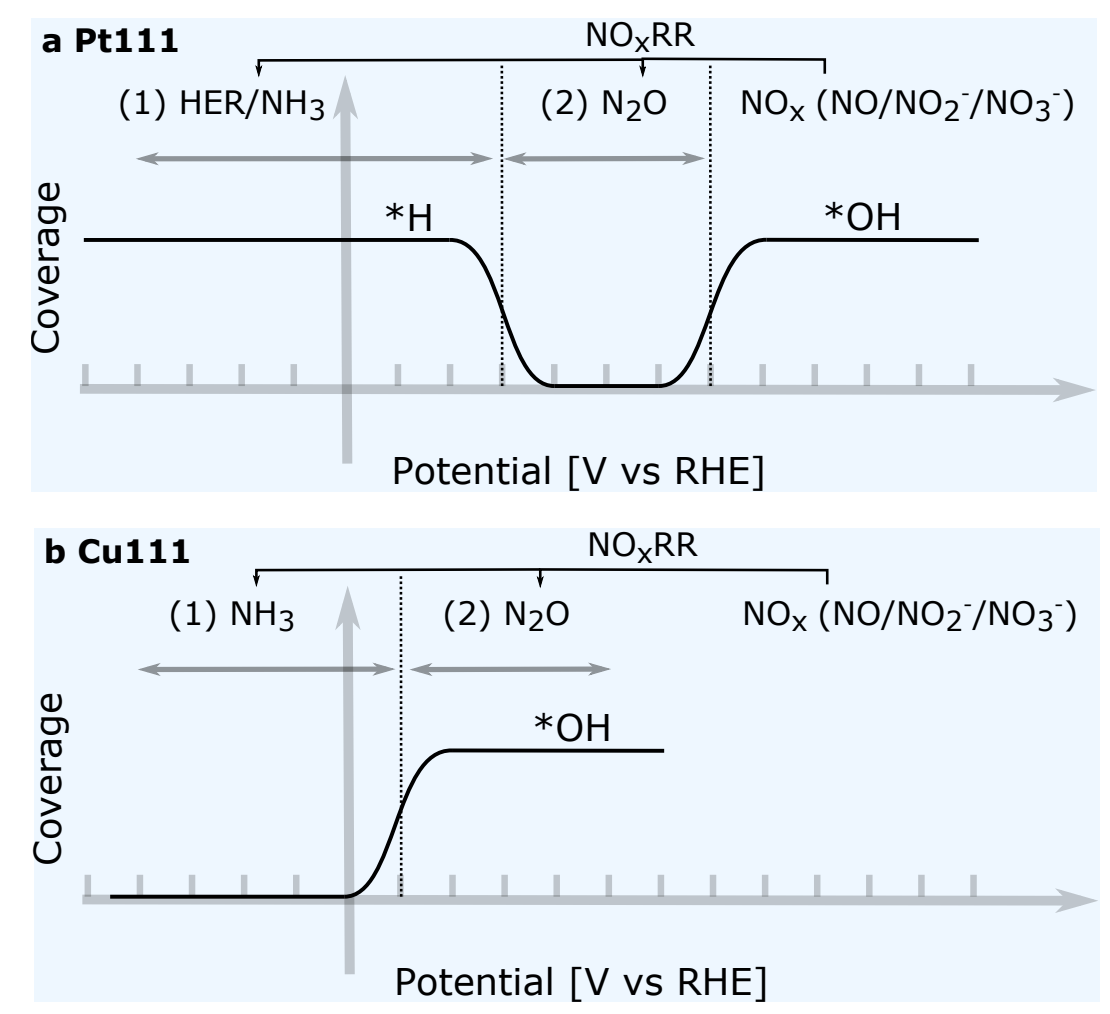

Figure 1: Schematic representation of experimental products from NO reduction on (a) $\mathrm{Pt}(111)$ and (b) $\mathrm{Cu}(111)$ and the relation to surface coverage. Two potential regions are shown with different product formation.

\section{Electrochemical reduction of $\mathrm{NO}_{3}{ }^{-} / \mathrm{NO}_{2}{ }^{-} / \mathrm{NO}$}

The electrochemical conversion of $\mathrm{NO}_{3}{ }^{-}$under reduction condition is complex, involving multiple reactions, products and stable intermediates (e.g., ammonia, nitrite, hydroxylamine, nitric oxide, nitrous oxide) spanning the many nitrogen oxidation states (from -III up to $+\mathrm{V}$ ). With referring to the reversible hydrogen electrode potential (RHE), the reduction products 
would be produced following the reactions below:

$$
\begin{array}{cc}
2 \mathrm{NO}_{3}{ }^{-}+12 \mathrm{H}^{+}+10 \mathrm{e}^{-} \longrightarrow \mathrm{N}_{2}+6 \mathrm{H}_{2} \mathrm{O} & E^{0}=1.25 \mathrm{~V} \\
2 \mathrm{NO}_{3}{ }^{-}+10 \mathrm{H}^{+}+8 \mathrm{e}^{-} \longrightarrow \mathrm{N}_{2} \mathrm{O}+5 \mathrm{H}_{2} \mathrm{O} & E^{0}=1.12 \mathrm{~V} \\
\mathrm{NO}_{3}{ }^{-}+4 \mathrm{H}^{+}+3 \mathrm{e}^{-} \longrightarrow \mathrm{NO}+2 \mathrm{H}_{2} \mathrm{O} & E^{0}=0.96 \mathrm{~V} \\
\mathrm{NO}_{3}{ }^{-}+2 \mathrm{H}^{+}+2 \mathrm{e}^{-} \longrightarrow \mathrm{NO}_{2}{ }^{-}+\mathrm{H}_{2} \mathrm{O} & E^{0}=0.94 V \\
\mathrm{NO}_{3}{ }^{-}+9 \mathrm{H}^{+}+8 \mathrm{e}^{-} \longrightarrow \mathrm{NH}_{3}+3 \mathrm{H}_{2} \mathrm{O} & E^{0}=0.88 V \\
\mathrm{NO}_{3}{ }^{-}+7 \mathrm{H}^{+}+6 \mathrm{e}^{-} \longrightarrow \mathrm{NH}_{2} \mathrm{OH}+2 \mathrm{H}_{2} \mathrm{O} & E^{0}=0.73 \mathrm{~V}
\end{array}
$$

As for the $\mathrm{NO}_{2}{ }^{-}$reduction process:

$$
\begin{array}{cc}
2 \mathrm{NO}_{2}{ }^{-}+8 \mathrm{H}^{+}+6 \mathrm{e}^{-} \longrightarrow \mathrm{N}_{2}+4 \mathrm{H}_{2} \mathrm{O} & E^{0}=1.45 V \\
2 \mathrm{NO}_{2}{ }^{-}+6 \mathrm{H}^{+}+4 \mathrm{e}^{-} \longrightarrow \mathrm{N}_{2} \mathrm{O}+3 \mathrm{H}_{2} \mathrm{O} & E^{0}=1.29 V \\
\mathrm{NO}_{2}{ }^{-}+2 \mathrm{H}^{+}+\mathrm{e}^{-} \longrightarrow \mathrm{NO}+\mathrm{H}_{2} \mathrm{O} & E^{0}=1.00 V \\
\mathrm{NO}_{2}{ }^{-}+7 \mathrm{H}^{+}+6 \mathrm{e}^{-} \longrightarrow \mathrm{NH}_{3}+2 \mathrm{H}_{2} \mathrm{O} & E^{0}=0.86 V \\
\mathrm{NO}_{2}{ }^{-}+5 \mathrm{H}^{+}+4 \mathrm{e}^{-} \longrightarrow \mathrm{NH}_{2} \mathrm{OH}+\mathrm{H}_{2} \mathrm{O} & E^{0}=0.62 V
\end{array}
$$

Electrochemical NO reduction reaction (NORR) has been studied under a variety of reaction conditions, including reactions on different metal electrodes, ${ }^{222} 25$ and varying NO concentrations. ${ }^{22226}$ Overall, there are four different products depending on potential observed during NORR process:

$$
\begin{array}{ll}
2 \mathrm{NO}+4\left(\mathrm{H}^{+}+\mathrm{e}^{-}\right) \longrightarrow \mathrm{N}_{2}+2 \mathrm{H}_{2} \mathrm{O} & E^{0}=1.68 V \\
2 \mathrm{NO}+2\left(\mathrm{H}^{+}+\mathrm{e}^{-}\right) \longrightarrow \mathrm{N}_{2} \mathrm{O}+\mathrm{H}_{2} \mathrm{O} & E^{0}=1.59 V \\
\mathrm{NO}+5\left(\mathrm{H}^{+}+\mathrm{e}^{-}\right) \longrightarrow \mathrm{NH}_{3}+\mathrm{H}_{2} \mathrm{O} & E^{0}=0.71 V \\
\mathrm{NO}+3\left(\mathrm{H}^{+}+\mathrm{e}^{-}\right) \longrightarrow \mathrm{NH}_{2} \mathrm{OH} & E^{0}=0.38 V
\end{array}
$$


Except the reactions mentioned above, the competitive hydrogen evolution reaction (HER) becomes pronounced when potential goes below $0 \mathrm{~V}$ vs RHE:

$$
2\left(\mathrm{H}^{+}+\mathrm{e}^{-}\right) \longrightarrow \mathrm{H}_{2} \quad E^{0}=0 \mathrm{~V}
$$

Thus, below $0 \mathrm{~V}$ (vs RHE), the observed Faradaic efficiencies, or percent of electrons used in NORR, can be greatly impacted. All the reactions described above from $\mathrm{NO}_{3}{ }^{-} / \mathrm{NO}_{2}{ }^{-} / \mathrm{NO}$, illustrate that adsorbed nitric oxide $(* \mathrm{NO})$ as divergent center, may control the electrocatalytic selectivity towards $\mathrm{N}_{2} \mathrm{O}, \mathrm{N}_{2}, \mathrm{NH}_{2} \mathrm{OH}$ and $\mathrm{NH}_{3}$ as illustrated in Fig. 2. As a result, the affinity to NO on metals will play an essential role in their reduction selectivity performance.

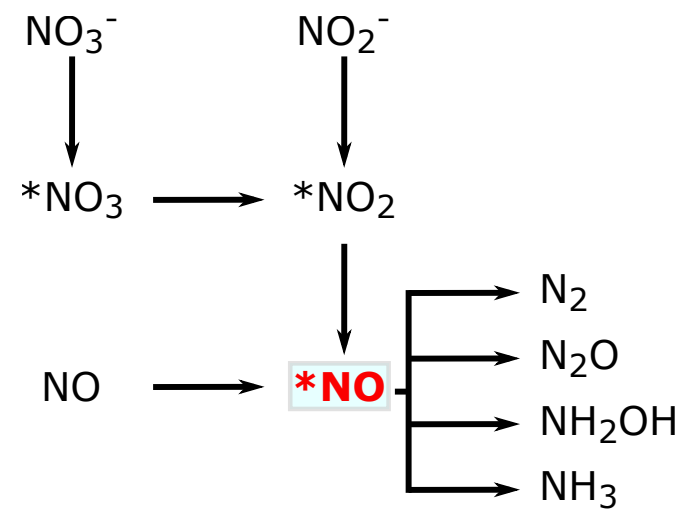

Figure 2: Schematic representation of $\mathrm{NO}_{3}{ }^{-} / \mathrm{NO}_{2}{ }^{-} / \mathrm{NO}$ reduction pathways.

\section{Results and Discussion}

Fig. 1(a) shows for Pt that there are two major reaction regions for NO reduction:

- at low potential ( $<0.3 \mathrm{~V}$ vs RHE) where both $\mathrm{H}_{2}$ and $\mathrm{NH}_{3}$ are observed, and at the potential below $0 \mathrm{~V}$ vs $\mathrm{RHE}, \mathrm{H}_{2}$ becomes the main product.

- at high potential (0.3 - $0.7 \mathrm{~V}$ vs $\mathrm{RHE})$ which leads to $\mathrm{N}_{2} \mathrm{O}$ formation.

Similar potential regions have been observed on other metals, such as $\mathrm{Pd}, \mathrm{Rh}, \mathrm{Ru}, \mathrm{Ir}$ and $\mathrm{Au}$. As a comparison, Fig. 1 (b) shows $\mathrm{Cu}$ producing $\mathrm{NH}_{3}$ as the main product at low potential $\left(<0 \mathrm{~V}\right.$ vs RHE) and $\mathrm{N}_{2} \mathrm{O}$ above $0 \mathrm{~V}$ vs RHE. 


\section{NORR under Low Potential}

To conduct electrocatalytic $\mathrm{NO}_{x}$ reduction on catalysts, $\mathrm{NO}_{x}$ species are expected to be adsorbed on the surfaces. In addition, the competition from HER also has to be avoided, especially under low potential region.

Fig. 3(a) shows the adsorption energies of $* \mathrm{NO}_{3}$ plotted against $* \mathrm{H}$ adsorption energy. The horizontal line in Fig. 3(a) shows the equilibrium between $\mathrm{NO}_{3}{ }^{-}$and adsorbed $* \mathrm{NO}_{3}$ while the vertical line depicts the equilibrium between $(1 / 2) \mathrm{H}_{2}$ and adsorbed $* \mathrm{H}$ under standard conditions. It is found that almost all metals investigated here can absorb $* \mathrm{NO}_{3}$, except Au (Fig. 3(a)). As a result, all metals, except Au might obtain the electroccatalytic activity for $\mathrm{NO}_{3}{ }^{-}$reduction, while on $\mathrm{Au}$, the electroreduction of $\mathrm{NO}_{3}{ }^{-}$is hardly detectable as reported experimentally. $\frac{15}{15}$ As for the adsorption of $* \mathrm{H}$, there are three binding energy regimes: i) binding $* \mathrm{H}$ weakly, limiting availability towards adsorbed $* \mathrm{H}$ paves high barrier for their catalytic activity of $\mathrm{NO}_{3}{ }^{-}$reduction $(\mathrm{Ag} / \mathrm{Au})$; ii) binding $* \mathrm{H}$ moderately but still above $0 \mathrm{eV}(\mathrm{Cu})$ and iii) the remaining metals to the left of vertical line bind $* \mathrm{H}$ strongly, mainly resulting in HER instead of $\mathrm{NO}_{3}{ }^{-}$reduction, especially at potential below $0 \mathrm{~V}$ vs RHE.
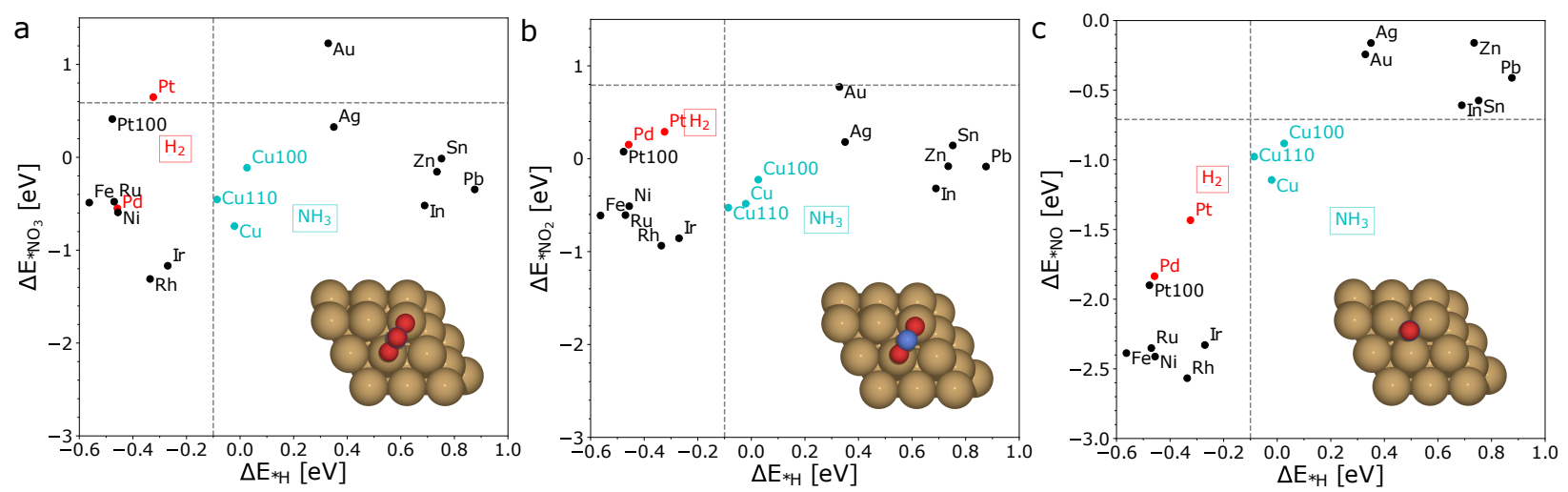

Figure 3: The adsorption energies of the intermediates (a): $\Delta E_{* \mathrm{NO}_{3}}$; (b) $\Delta E_{* \mathrm{NO}_{2}}$ and (c) $\Delta E_{* \mathrm{NO}}$ are plotted against $\Delta E_{* \mathrm{H}}$. The horizontal line shows the equilibrium between (a) $\mathrm{NO}_{3}{ }^{-}$and adsorbed $* \mathrm{NO}_{3}$; (b) $\mathrm{NO}_{2}{ }^{-}$and adsorbed $* \mathrm{NO}_{2} ;$ (c) $\mathrm{NO}$ (gas) and adsorbed $* \mathrm{NO}$ while the vertical line depicts the equilibrium between $(1 / 2) \mathrm{H}_{2}$ and adsorbed $* \mathrm{H}$ under standard conditions. Red makers demonstrates $\mathrm{H}_{2}$ produced as the main product while Cyan color markers shows $\mathrm{NH}_{3}$ is the main product according to experimental results. .910125127$\left.] 29\right]$ 
Fig. 3(b) illustrates the adsorption energies of $* \mathrm{NO}_{2}$ is plotted against $* \mathrm{H}$ adsorption energy. The horizontal line shows the equilibrium between $\mathrm{NO}_{2}{ }^{-}$and adsorbed $* \mathrm{NO}_{2}$ and again the vertical line describes the equilibrium between $(1 / 2) \mathrm{H}_{2}$ and adsorbed $* \mathrm{H}$. The adsorption tendency towards $* \mathrm{NO}_{2}$ are observed similar to $* \mathrm{NO}_{3}$, except Au. Au binds $* \mathrm{NO}_{2}$ stronger than $* \mathrm{NO}_{3}$, and is close to the equilibrium between $\mathrm{NO}_{2}{ }^{-}$and $* \mathrm{NO}_{2}$, leading to some catalytic activity of $\mathrm{NO}_{2}{ }^{-}$reduction ${ }^{17}$. Similar to $\mathrm{NO}_{3}{ }^{-}$reduction, for $\mathrm{NO}_{2}{ }^{-}$reduction, the metals to the left of vertical line binding $* \mathrm{H}$ strongly, produces $\mathrm{H}_{2}$ as the main product under low potential. For the metals to the right of the vertical line, binding $* \mathrm{H}$ weakly, like $\mathrm{Ag}$ and $\mathrm{Au}$, catalytic $\mathrm{NO}_{2}{ }^{-}$reduction is unfavorable due to limiting accessibility of adsorbed $* \mathrm{H}$. As for $\mathrm{Cu}$, it adsorbs $* \mathrm{NO}_{2}$ and produces $\mathrm{NH}_{3}$ with limited HER.

Fig. 3(c) shows the adsorption energies of $* \mathrm{NO}$ plotted against $* \mathrm{H}$ adsorption energy. The horizontal line illustrates the equilibrium between $\mathrm{NO}$ (gas) and adsorbed $* \mathrm{NO}$ and the vertical line shows the equilibrium between $(1 / 2) \mathrm{H}_{2}$ and adsorbed $* \mathrm{H}$. Fig. 3(c) illustrates that metals can be classified into three groups in terms of the adsorption energies for $* \mathrm{NO}$ and $* \mathrm{H}$. Metals on the left of vertical line like $\mathrm{Pt}, \mathrm{Pd}$, bind both $* \mathrm{NO}$ and $* \mathrm{H}$ very strongly, resulting in HER at potential below $0 \mathrm{~V}$ vs RHE. For the metals above the horizontal line, it is unfavourable to bind $* \mathrm{NO}$, which does not allow $\mathrm{NO}$ reduction. Only $\mathrm{Cu}$ metal binds $* \mathrm{NO}$ while not having $* \mathrm{H}$ upd, leading to $\mathrm{NH}_{3}$ conversion.

The analysis above, shows that $\mathrm{NO}_{x}\left(\mathrm{NO}_{3}{ }^{-}, \mathrm{NO}_{2}{ }^{-}\right.$and $\left.\mathrm{NO}\right)$ reduction on the metals to the left of the vertical line in Fig. 3 is greatly inhibited by HER, leading to low $\mathrm{NO}_{x}$ product faradic efficiency. For the metals above the horizontal line in Fig. 3(c), $\mathrm{NO}_{x}\left(\mathrm{NO}_{3}{ }^{-}\right.$, and $\mathrm{NO}_{2}{ }^{-}$) reduction can happen with sufficient potential applied, producing $\mathrm{NO}$ while further reduction of $\mathrm{NO}$ is hard. $\mathrm{Cu}$ stands out with the unique property that it can bind $* \mathrm{NO}_{3}$, $* \mathrm{NO}_{2}$ and $* \mathrm{NO}$ but not $* \mathrm{H}$, demonstrating its high selectivity for $\mathrm{NO}_{x}$ reduction over HER. This is similar to $\mathrm{CO}_{2} / \mathrm{CO}$ electroreduction. 20

Fig. 4 demonstrates computational limiting potential for $\mathrm{NO}$ reduction towards $\mathrm{NH}_{3}$ plotted against the adsorption energy of $* \mathrm{~N}\left(\Delta \mathrm{G}_{* \mathrm{~N}}\right)$ with the utilization of the scaling re- 
lations presented in Fig. S2. The red line represents the strong binding side of the volcano where the hydrogenation of $* \mathrm{NH}$ to $* \mathrm{NHH}$ is limiting step. The blue line shows metals with weak binding of $* \mathrm{~N}$. For the metals on the weak binding side, $* \mathrm{NHO}$ is preferred in the protonation of $* \mathrm{NO}$, and $\mathrm{NH}_{3}$ will be produced via $* \mathrm{NHHO}$ intermediate, leaving $* \mathrm{O}$ on the surface as shown in Fig. S4. On the weak binding side, $\mathrm{Cu}$ prefers $* \mathrm{NOH}$ while $* \mathrm{NHO}$ is formed on $\mathrm{Ag}$ or $\mathrm{Au}$ in the hydrogenation of $* \mathrm{NO}$. Further hydrogenation of $* \mathrm{NOH}$ on $\mathrm{Cu}$ produces $* \mathrm{~N}$ and then continuous protonation of $* \mathrm{~N}$ leads to the formation of $\mathrm{NH}_{3}$. Among all the metals investigated here, $\mathrm{Cu}$ is predicted to be the most active catalyst to produce $\mathrm{NH}_{3}$. 


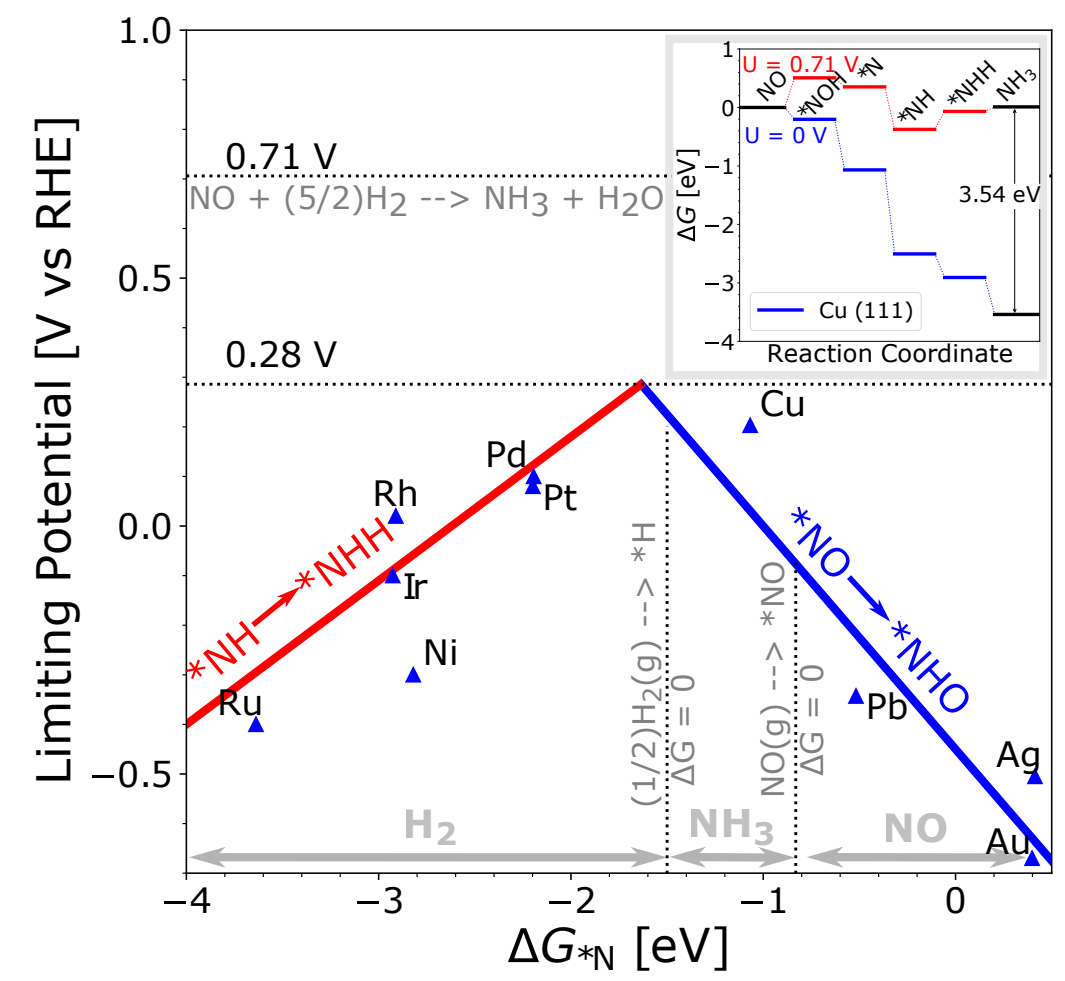

Figure 4: The limiting potential volcano for $\mathrm{NO}$ reduction to $\mathrm{NH}_{3}$. Limiting potential defined as the negative of the free energy change of each proton-coupled electron transfer step, which behaves as a function of the adsorption energy of $* \mathrm{~N}\left(\Delta \mathrm{G}_{* \mathrm{~N}}\right)$ at $0 \mathrm{~V}$ vs RHE. The left red line demonstrates the potential is limited by the strong binding of $* \mathrm{NH}(* \mathrm{NH}$ towards $* \mathrm{NHH})$ while the right blue line shows that the potential is limited by the weak binding of $*$ NHO (formation of $* \mathrm{NHO}$ from $* \mathrm{NO}$ ). The upper dashed horizontal line exhibits the equilibrium potential $(0.71 \mathrm{~V})$ which can be obtained from $\mathrm{NO}$ reduction to $\mathrm{NH}_{3}$. The vertical lines shows the $* \mathrm{H}$ and $* \mathrm{NO}$ adsorption respectively. Insert: Free energy diagram of $\mathrm{NO}$ reduction towards $\mathrm{NH}_{3}$ on $\mathrm{Cu}(111)$, with blue line constructed under $0 \mathrm{~V}$ while red line constructed under equilibrium potential $(0.71 \mathrm{~V})$. Note $\mathrm{Cu}$ is the only metal on the weak binding side but prefers $* \mathrm{NOH}$.

A closer catalytic reaction process on $\mathrm{Cu}(111)$ can be seen in the insert of Fig. 4 . It proceeds via the protonation of the adsorbed $* \mathrm{NO}$ to $* \mathrm{NOH}$ intermediate, and further protonation of $* \mathrm{~N}$ and $* \mathrm{NH}$ leads to $\mathrm{NH}_{3}$ formation. The first hydrogenation of $* \mathrm{NO}$ is the potential limiting step. As a result, $\mathrm{Cu}(111)$ provides the highest catalytic activity for $\mathrm{NH}_{3}$ formation among all metals investigated here, and its catalytic activity can be still enhanced by strengthening its $* \mathrm{~N}$ adsorption, since it is still not on the top of the volcano.

Following the scaling relation between $* \mathrm{~N}$ and $* \mathrm{H}$ and the scaling relation between $* \mathrm{~N}$ 
and $*$ NO shown Fig. S5, the product selectivity (vertical dashed lines) can be also indicated in Fig. 4. When $\Delta \mathrm{G}_{* \mathrm{~N}}$ is smaller than $-1.5 \mathrm{eV}, \Delta \mathrm{G}_{* \mathrm{H}}$ becomes negative and $\mathrm{H}_{2}$ will be the main product. For metals with $\Delta \mathrm{G}_{* \mathrm{~N}}$ larger than $-0.83 \mathrm{eV}$, the adsorption of $* \mathrm{NO}$ is unfavorable, leading to the formation of NO. $\mathrm{Cu}$ has $\Delta \mathrm{G}_{* \mathrm{~N}}$ between $-1.5 \mathrm{eV}$ and $-0.83 \mathrm{eV}$, leading to high selectivity for $\mathrm{NH}_{3}$ production in the process of NORR, as also seen in Fig. Fig. 3.

This computational analysis explains that the experimental results with high faradaic efficiency $(>90 \%)$ for $\mathrm{NO}_{x}\left(\mathrm{NO}_{3}{ }^{-}, \mathrm{NO}_{2}{ }^{-}\right.$and $\left.\mathrm{NO}\right)$ reduction to $\mathrm{NH}_{3}$ have been achieved on $\mathrm{Cu}$-based catalysts. .011125$] 30,34$ More interestingly, enhanced catalytic activity has also been observed when $\mathrm{Cu}$ is alloyed with strong $* \mathrm{~N}$ adsorption metals, like $\mathrm{Ni}$ and $\mathrm{Rh}$.1131 33 This might be due to the stabilization of $* \mathrm{NOH}$ intermediate, getting close to the top of the volcano shown in Fig. $4(\mathrm{a})$ but still $\Delta \mathrm{G}_{* \mathrm{~N}}$ in the region of $-1.5 \mathrm{eV}$ to $-0.83 \mathrm{eV}$. At medium potentials (around $0-0.3 \mathrm{~V}$ vs RHE), the HER is thermodynamically impossible and $\mathrm{NH}_{3}$ is reported as the major product ${ }^{24}$. With limited access to adsorbed $* \mathrm{H}$, much less current

density is observed experimentally for the metals. 15 17724 Still, much higher current density at medium potential is reported on $\mathrm{Cu}$ for $\mathrm{NO}_{x}\left(\mathrm{NO}_{3}{ }^{-}, \mathrm{NO}_{2}{ }^{-}\right.$and $\left.\mathrm{NO}\right)$ reduction under the same experimental conditions, compared to other transition metals.

\section{NORR towards $\mathrm{N}_{2} \mathrm{O}$ under High Potential}

At high potential region, $\mathrm{N}_{2} \mathrm{O}$ formation is observed. For this reaction to occur, $\mathrm{N}-\mathrm{N}$ coupling is required. Fig. 5(a) shows that the $*$ ONNO formation on metals from $2 \mathrm{NO}$ is unfavourable. Experimentally, it has been suggested that solution NO is involved in the reaction sequence to produce $\mathrm{N}_{2} \mathrm{O}$ since $\mathrm{N}_{2} \mathrm{O}$ is not produced during the reduction of adsorbed $* \mathrm{NO} \cdot{ }^{24}$ It seems more reasonable to speculate $\mathrm{N}-\mathrm{N}$ bond formation from $* \mathrm{~N}$ and $\mathrm{NO}$. As for the formation of $* \mathrm{~N}$, besides the continuous protonation of $\mathrm{NO}_{x}$, the dissociation of $\mathrm{NO}_{x}$ can be another option. Fig. S3 (a-c) present the activation barriers for $\mathrm{NO}_{x}$ dissociation. $\mathrm{Ni}$ and $\mathrm{Rh}$ have the lowest barriers whereas Ag or Au have the highest barrier. Generally, the barriers for 
$\mathrm{Cu}$ and the platinum group metals is between the two extremes. For the $* \mathrm{NO}_{x}(\mathrm{x}=1,2$, and 3) dissociation reactions, $E_{a}$ increases with decreasing $\mathrm{x}$ on a specific metal, implying that the final dissociation step has the highest activation energy. As a result, $* \mathrm{~N}$ might be produced via the dissociation of $* \mathrm{NO}_{3}$ and $* \mathrm{NO}_{2}$ and then the hydrogenation of $* \mathrm{NO}$.
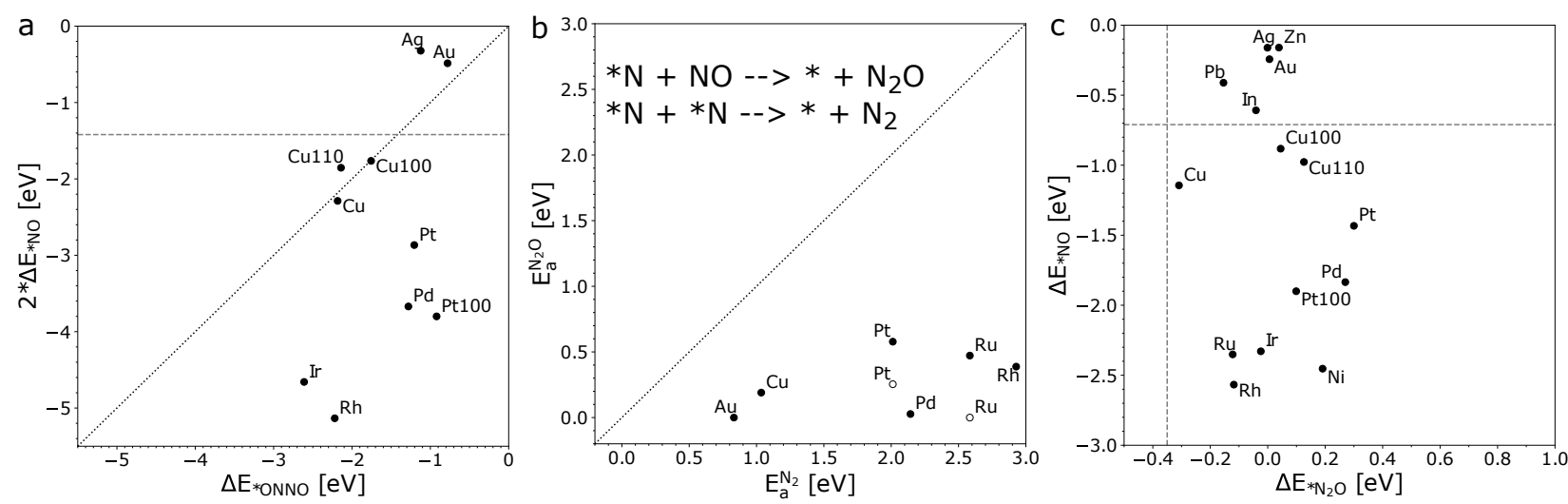

Figure 5: (a)Adsorption energy comparison between twice of $* \mathrm{NO}$ and $\mathrm{N}-\mathrm{N}$ coupling intermediate $* \mathrm{ONNO}$. The horizontal line shows the equilibrium between $2 \mathrm{NO}(\mathrm{g})$ and $2 * \mathrm{NO}$, while the diagonal line illustrates the equal adsorption energy between $2 * \mathrm{NO}$ and $* \mathrm{ONNO}$. (b)The activation barriers for $\mathrm{N}-\mathrm{N}$ coupling between $* \mathrm{~N}$ and $\mathrm{NO}$ (gas) vs $* \mathrm{~N}$ and $* \mathrm{~N}$. where the unfilled markers show around 0.44 Monolayer of NO coverage is considered. (c) Adsorption energy comparison between $* \mathrm{NO}$ and $* \mathrm{~N}_{2} \mathrm{O}$. The horizontal line shows the equilibrium between $\mathrm{NO}(\mathrm{g})$ and $* \mathrm{NO}$ while the vertical line depicts the equilibrium between $\mathrm{N}_{2} \mathrm{O}$ and $* \mathrm{~N}_{2} \mathrm{O}$ under standard conditions.

Fig. 5(b) shows the activation barrier for $\mathrm{N}-\mathrm{N}$ bond formation between adsorbed $* \mathrm{~N}$ and NO plotted against the activation barrier of $\mathrm{N}_{2}$ formation from two adsorbed $* \mathrm{~N}$. There is almost no activation observed for $\mathrm{N}-\mathrm{N}$ coupling between $* \mathrm{~N}$ and $\mathrm{NO}$ except $\mathrm{Ru}$, no matter how strong $* \mathrm{~N}$ is adsorbed. Following the experiments, where 0.5 monolayer $* \mathrm{NO}$ coverage has been suggested on strong adsorption metals like $\mathrm{Ru}, \stackrel{24}{24} * \mathrm{~N}$ and $\mathrm{NO}$ coupling becomes feasible with this coverage consideration. In addition, the activation barrier of $\mathrm{N}_{2}$ formation from adsorbed $* \mathrm{~N}$ is larger than $\mathrm{N}_{2} \mathrm{O}$ formation.

Fig. 5(c) shows the adsorption energy comparison between $* \mathrm{NO}$ and $* \mathrm{~N}_{2} \mathrm{O}$. The horizontal line shows the equilibrium between $\mathrm{NO}$ (gas) and $* \mathrm{NO}$ while the vertical line depicts the equilibrium between $\mathrm{N}_{2} \mathrm{O}$ (gas) and $* \mathrm{~N}_{2} \mathrm{O}$ under standard conditions. It shows that the adsorption of $\mathrm{N}_{2} \mathrm{O}$ is not stable for all metals. As a consequence, $\mathrm{N}_{2} \mathrm{O}$ will be the main 
product during $\mathrm{NO}_{x}$ reduction at high potential.

\section{Conclusions}

In this study, we use DFT simulations to investigate electrocatalytic $\mathrm{NO}_{x}$ reduction selectivity and activity over metal catalysts. Analogous to classifying $\mathrm{CO}_{2}$ reduction by $* \mathrm{CO}$ vs $* \mathrm{H}$, we classify metals by the adsorption energy of $* \mathrm{NO}$ vs $* \mathrm{H}$. Since the selectivity of the $\mathrm{NO}_{x}$ reduction is potential dependent, the products formation has been analysed in two different potential regions. At low potential, $\mathrm{NO}_{x}$ reduction competes with HER, leading to $\mathrm{H}_{2}$ as the major product on strong $* \mathrm{H}$ binding metals. For metals binding $* \mathrm{H}$ weakly like $\mathrm{Ag}$ or $\mathrm{Au}, \mathrm{NO}_{3}{ }^{-}$and $\mathrm{NO}_{2}{ }^{-}$reduction will stop at $\mathrm{NO}$ similar to $\mathrm{CO}_{2}$-to-CO. Cu stands out with the unique property that it can bind $* \mathrm{NO}_{3}, * \mathrm{NO}_{2}$ and $* \mathrm{NO}$ but not having $\mathrm{H}_{\text {upd }}$, leading to high selectivity for $\mathrm{NH}_{3}$ formation.

With the utilization of scaling relations for intermediates adsorption energies, DFT simulated limiting potential is plotted against the adsorption energy of $* \mathrm{~N}$. Cu is predicted to be the most active metal to conduct $\mathrm{NO}$ reduction towards $\mathrm{NH}_{3}$ and the potential limiting step is the hydrogenation of adsorbed $*$ NO. The volcano shows that enhanced activity can be achieved by slightly strengthening the adsorption energy of $* \mathrm{~N}$ on $\mathrm{Cu}$, like alloying $\mathrm{Cu}$ with metals binding $* \mathrm{~N}$ stronger but $\Delta \mathrm{G}_{* \mathrm{~N}}$ still should be larger than $-1.5 \mathrm{eV}$. At potential between 0 to $0.3 \mathrm{~V}$ vs $\mathrm{RHE}$, the limiting adsorbed $* \mathrm{H}$ results in much less current density compared to that under low potential for $\mathrm{NO}_{x}$ reduction. Still $\mathrm{NH}_{3}$ is reported as the main product and $\mathrm{Cu}$ demonstrates higher current density under the same conditions as compared to other transition metals.

At high potential condition ( $>0.3 \mathrm{~V}$ vs RHE), high coverage of adsorbed $* \mathrm{NO}$ is observed for NO reduction. With free $\mathrm{NO}$ in the solution, the N-N bond formation from adsorbed $* \mathrm{~N}$ and $\mathrm{NO}$, forming $\mathrm{N}_{2} \mathrm{O}$, is feasible while it is impossible to produce $\mathrm{N}_{2}$ via the association of two adsorbed $* \mathrm{~N}$. 
These descriptor-based analyses in this work provide a description of the NO reduction or even $\mathrm{NO}_{3}{ }^{-}$and $\mathrm{NO}_{2}{ }^{-}$reduction network on metals at atomic scale. These findings offer a guidance or inspiration for the design and discovery of both selective and active $\mathrm{NO}_{x}\left(\mathrm{NO}_{3}{ }^{-}\right.$, $\mathrm{NO}_{2}{ }^{-}$and $\mathrm{NO}$ ) reduction electrocatalysts.

\section{Computational Details}

The computational analysis was carried out using the grid-based projector-augmented wave (GPAW) method, a DFT code based on a projected augmented wave (all-electron frozen core approximation) method integrated with the atomic simulation environment (ASE). 35 -37 The revised Perdew-Burke-Ernzerhof (RPBE) functional was used as an exchange-correlation functional. $\frac{38}{38}$ The wavefunctions were represented on a uniform real-spaced grid with 0.18 $\AA$ grid-spacing. The electronic spins are treated separately, and a vacuum of minimum 7 $\AA$ was employed. Besides the calculation for climbing image nudged elastic band (NEB) was performed with GPAW code. ${ }^{39}$ The quasi-Newton minimization scheme was employed for the geometry optimizations, and the systems were relaxed until the forces were less than

$0.05 \mathrm{eV} / \AA$. Structures, total energies, scripts to run calculations, and plotting methods are collected in the KatlaDB database available at this link: http://nano.ku.dk/english/ research/theoretical-electrocatalysis/katladb/.

\section{Acknowledgement}

We acknowledge support from the Danish Council for Independent Research Sapere Aude Program, Grant No. 11-1051390, research grant 9455 from VILLUM FONDEN and Innovation Fund Denmark (grand solution ProActivE 5124-00003A). The Center for High Entropy Alloys Catalysis is sponsored by the Danish National Research Foundation centers of excellence, Project DNRF149. 


\section{References}

(1) Galloway, J. N.; Townsend, A. R.; Erisman, J. W.; Bekunda, M.; Cai, Z.; Freney, J. R.; Martinelli, L. A.; Seitzinger, S. P.; Sutton, M. A. Transformation of the Nitrogen Cycle: Recent Trends, Questions, and Potential Solutions. Science 2008, 320, 889-892.

(2) Canfield, D. E.; Glazer, A. N.; Falkowski, P. G. The Evolution and Future of Earth's Nitrogen Cycle. Science 2010, 330, 192-196.

(3) Cole, J. A.; Benjamin, N.; Lundberg, J. O.; Weitzberg, E. Nitrate, bacteria and human health. Nature reviews. Microbiology 2004, 2, 593-602.

(4) Gruber, N.; Galloway, J. N. An Earth-system perspective of the global nitrogen cycle. Nature 2008, 451, 293-296.

(5) Pennino, M. J.; Compton, J. E.; Leibowitz, S. G. Trends in Drinking Water Nitrate Violations Across the United States. Environ. Sci. Technol. 2017, 51, 13450-13460.

(6) Rosca, V.; Duca, M.; de Groot, M. T.; Koper, M. T. M. Nitrogen Cycle Electrocatalysis. Chem. Rev. 2009, 109, 2209-2244, DOI: 10.1021/cr8003696.

(7) Duca, M.; Koper, M. T. M. Powering denitrification: the perspectives of electrocatalytic nitrate reduction. Energy Environ. Sci. 2012, 5, 9726-9742, DOI: 10.1039/C2EE23062C.

(8) Bae, S.-E.; Stewart, K. L.; Gewirth, A. A. Nitrate Adsorption and Reduction on $\mathrm{Cu}(100)$ in Acidic Solution. J. Am. Chem. Soc. 2007, 129, 10171-10180, DOI: 10.1021/ja071330n, PMID: 17655297.

(9) Garcia-Segura, S.; Lanzarini-Lopes, M.; Hristovski, K.; Westerhoff, P. Electrocatalytic reduction of nitrate: Fundamentals to full-scale water treatment applications. Appl. Catal. B 2018, 236, 546-568, DOI: 10.1016/j.apcatb.2018.05.041. 
(10) Wang, Y.; Zhou, W.; Jia, R.; Yu, Y.; Zhang, B. Unveiling the Activity Origin of a Copper-based Electrocatalyst for Selective Nitrate Reduction to Ammonia. Angew. Chem. Int. Ed. 2020, 59, 5350-5354.

(11) Wang, Y.; Xu, A.; Wang, Z.; Huang, L.; Li, J.; Li, F.; Wicks, J.; Luo, M.; Nam, D.H.; Tan, C.-S.; Ding, Y.; Wu, J.; Lum, Y.; Dinh, C.-T.; Sinton, D.; Zheng, G.; Sargent, E. H. Enhanced Nitrate-to-Ammonia Activity on Copper-Nickel Alloys via Tuning of Intermediate Adsorption. J. Am. Chem. Soc. 2020, 142, 5702-5708, DOI: 10.1021/jacs.9b13347, PMID: 32118414 .

(12) van Langevelde, P. H.; Katsounaros, I.; Koper, M. T. Electrocatalytic Nitrate Reduction for Sustainable Ammonia Production. Joule 2021, 5, 290-294, DOI: https://doi.org/10.1016/j.joule.2020.12.025.

(13) Li, P.; Jin, Z.; Fang, Z.; Yu, G. A single-site iron catalyst with preoccupied active centers that achieves selective ammonia electrosynthesis from nitrate. Energy Environ. Sci. 2021,-, DOI: 10.1039/D1EE00545F.

(14) Wu, Z.-Y.; Karamad, M.; Yong, X.; Huang, Q.; Cullen, D. A.; Zhu, P.; Xia, C.; Xiao, Q.; Shakouri, M.; Chen, F.-Y.; Kim, J. Y.; Xia, Y.; Heck, K.; Hu, Y.; Wong, M. S.; Li, Q.; Gates, I.; Siahrostami, S.; Wang, H. Electrochemical ammonia synthesis via nitrate reduction on Fe single atom catalyst. Nat. commun. 2021, 12.

(15) Dima, G.; de Vooys, A.; Koper, M. Electrocatalytic reduction of nitrate at low concentration on coinage and transition-metal electrodes in acid solutions. J. electroanal. chem. 2003, 554-555, 15-23.

(16) de Groot, M.; Koper, M. The influence of nitrate concentration and acidity on the electrocatalytic reduction of nitrate on platinum. J. electroanal. chem. 2004, 562, 8194. 
(17) Duca, M.; van der Klugt, B.; Koper, M. Electrocatalytic reduction of nitrite on transition and coinage metals. Electrochimica Acta 2012, 68, 32-43, DOI: 10.1016/j. electacta.2012.02.037.

(18) Chun, H.-J.; Apaja, V.; Clayborne, A.; Honkala, K.; Greeley, J. Atomistic Insights into Nitrogen-Cycle Electrochemistry: A Combined DFT and Kinetic Monte Carlo Analysis of NO Electrochemical Reduction on Pt(100). ACS Cataly. 2017, 7, 3869-3882, DOI: 10.1021/acscatal.7b00547.

(19) Casey-Stevens, C. A.; Ásmundsson, H.; Skúlason, E.; Garden, A. L. A density functional theory study of the mechanism and onset potentials for the major products of NO electroreduction on transition metal catalysts. Applied Surface Science 2021, 552, 149063, DOI: $10.1016 / j$.apsusc.2021.149063.

(20) Bagger, A.; Ju, W.; Varela, A. S.; Strasser, P.; Rossmeisl, J. Electrochemical CO2 Reduction: A Classification Problem. ChemPhysChem 2017, 18, 3266-3273, DOI: $10.1002 / \mathrm{cphc} .201700736$.

(21) Wan, H.; Jiao, Y.; Bagger, A.; Rossmeisl, J. Three-Dimensional Carbon Electrocatalysts for $\mathrm{CO} 2$ or CO Reduction. ACS Catal. 2021, 11, 533-541, DOI: 10.1021/acscatal.0c04878.

(22) de Vooys, A.; Koper, M.; van Santen, R.; van Veen, J. Mechanistic study of the nitric oxide reduction on a polycrystalline platinum electrode. Electrochim. acta 2001, 46, 923-930.

(23) de Vooys, A.; Beltramo, G.; van Riet, B.; van Veen, J.; Koper, M. Mechanisms of electrochemical reduction and oxidation of nitric oxide. Electrochim. acta 2004, 49, $1307-1314$.

(24) de Vooys, A.; Koper, M.; van Santen, R.; van Veen, J. Mechanistic Study on the 
Electrocatalytic Reduction of Nitric Oxide on Transition-Metal Electrodes. J. catal. 2001, 202, 387-394.

(25) Long, J.; Chen, S.; Zhang, Y.; Guo, C.; Fu, X.; Deng, D.; Xiao, J. Direct Electrochemical Ammonia Synthesis from Nitric Oxide. Angew. Chem., Int. Ed. 2020, 59, 9711-9718.

(26) Cuesta, A.; Escudero, M. Electrochemical and FTIRS characterisation of NO adlayers on cyanide-modified Pt(111) electrodes: the mechanism of nitric oxide electroreduction on Pt. Phys. Chem. Chem. Phys. 2008, 10, 3628-.

(27) Pérez-Gallent, E.; Figueiredo, M. C.; Katsounaros, I.; Koper, M. T. Electrocatalytic reduction of Nitrate on Copper single crystals in acidic and alkaline solutions. Electrochimica Acta 2017, 227, 77-84, DOI: 10.1016/j.electacta.2016.12.147.

(28) Hasnat, M.; Ben Aoun, S.; Nizam Uddin, S.; Alam, M.; Koay, P.; Amertharaj, S.; Rashed, M.; Rahman, M. M.; Mohamed, N. Copper-immobilized platinum electrocatalyst for the effective reduction of nitrate in a low conductive medium: Mechanism, adsorption thermodynamics and stability. Applied Catalysis A: General 2014, 478, 259-266, DOI: 10.1016/j.apcata.2014.04.017.

(29) Soto-Hernández, J.; Santiago-Ramirez, C.; Ramirez-Meneses, E.; Luna-Trujillo, M.; Wang, J.-A.; Lartundo-Rojas, L.; Manzo-Robledo, A. Electrochemical reduction of $\mathrm{NOx}$ species at the interface of nanostructured $\mathrm{Pd}$ and $\mathrm{PdCu}$ catalysts in alkaline conditions. Applied Catalysis B: Environmental 2019, 259, 118048, DOI: $10.1016 / j$.apcatb.2019.118048.

(30) Reyter, D.; Chamoulaud, G.; Bélanger, D.; Roué, L. Electrocatalytic reduction of nitrate on copper electrodes prepared by high-energy ball milling. J. Electroanal. Chem. 2006, 596, 13-24, DOI: 10.1016/j.jelechem.2006.06.012. 
(31) Comisso, N.; Cattarin, S.; Fiameni, S.; Gerbasi, R.; Mattarozzi, L.; Musiani, M.; Vázquez-Gómez, L.; Verlato, E. Electrodeposition of $\mathrm{Cu}-\mathrm{Rh}$ alloys and their use as cathodes for nitrate reduction. Electrochem. Commun. 2012, 25, 91-93, DOI: $10.1016 / j$. elecom.2012.09.026.

(32) Mattarozzi, L.; Cattarin, S.; Comisso, N.; Guerriero, P.; Musiani, M.; VázquezGómez, L.; Verlato, E. Electrochemical reduction of nitrate and nitrite in alkaline media at CuNi alloy electrodes. Electrochim. Acta 2013, 89, 488-496, DOI: $10.1016 / \mathrm{j}$. electacta.2012.11.074.

(33) Mattarozzi, L.; Cattarin, S.; Comisso, N.; Gambirasi, A.; Guerriero, P.; Musiani, M.; Vázquez-Gómez, L.; Verlato, E. Hydrogen evolution assisted electrodeposition of porous $\mathrm{Cu}-\mathrm{Ni}$ alloy electrodes and their use for nitrate reduction in alkali. Electrochim. Acta 2014, 140, 337-344, DOI: 10.1016/j.electacta.2014.04.048, Electrochemistry for a New Era.

(34) Sun, J.; Alam, D.; Daiyan, R.; Masood, H.; Zhang, T.; Zhou, R.; Cullen, P. J.; Lovell, E. C.; Jalili, A. R.; Amal, R. A hybrid plasma electrocatalytic process for sustainable ammonia production. Energy Environ. Sci. 2021, 14, 865-872, DOI: 10.1039/D0EE03769A.

(35) Mortensen, J. J.; Hansen, L. B.; Jacobsen, K. W. Real-space grid implementation of the projector augmented wave method. Phys. Rev. B 2005, 71, 035109, DOI: 10.1103/PhysRevB.71.035109.

(36) Larsen, A. H.; Mortensen, J. J.; Blomqvist, J.; Castelli, I. E.; Christensen, R.; Dułak, M.; Friis, J.; Groves, M. N.; Hammer, B.; Hargus, C.; Hermes, E. D.; Jennings, P. C.; Jensen, P. B.; Kermode, J.; Kitchin, J. R.; Kolsbjerg, E. L.; Kubal, J.; Kaasbjerg, K.; Lysgaard, S.; Maronsson, J. B.; Maxson, T.; Olsen, T.; Pastewka, L.; Peterson, A.; Rostgaard, C.; Schiøtz, J.; Schütt, O.; Strange, M.; Thygesen, K. S.; 
Vegge, T.; Vilhelmsen, L.; Walter, M.; Zeng, Z.; Jacobsen, K. W. The atomic simulation environment - a Python library for working with atoms. J. Phys.: Condens. Matter 2017, 29, 273002.

(37) Bahn, S. R.; Jacobsen, K. W. An object-oriented scripting interface to a legacy electronic structure code. Comput. Sci. Eng. 2002, 4, 56-66, DOI: 10.1109/5992.998641.

(38) Hammer, B.; Hansen, L. B.; Nørskov, J. K. Improved adsorption energetics within density-functional theory using revised Perdew-Burke-Ernzerhof functionals. Phys. Rev. B 1999, 59, 7413-7421, DOI: 10.1103/PhysRevB.59.7413.

(39) Henkelman, G.; Uberuaga, B. P.; Jónsson, H. A climbing image nudged elastic band method for finding saddle points and minimum energy paths. J. Chem. Phys. 2000, 113, 9901-9904, DOI: 10.1063/1.1329672. 


\section{Graphical TOC Entry}

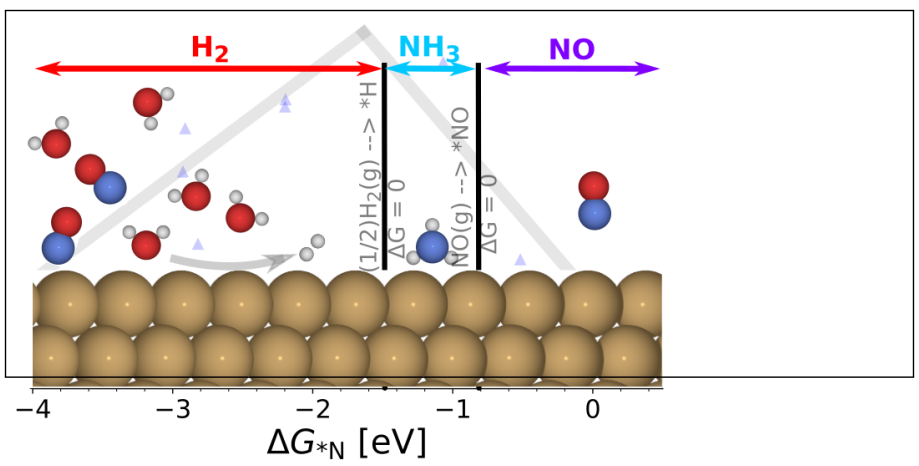

Illustration of selectivity and activity on metals for nitric reduction reaction 